\section{Cureus}

Received 03/19/2018

Review began 03/26/2018

Review ended 03/27/2018

Published 04/05/2018

\section{(c) Copyright 2018}

Nepal et al. This is an open access article distributed under the terms of the Creative Commons Attribution License CC-BY 3.0., which permits unrestricted use, distribution, and reproduction in any medium, provided the original author and source are credited.

\title{
Self-medication with Antibiotics in WHO Southeast Asian Region: A Systematic Review
}

\author{
Gaurav Nepal ${ }^{1}$, Shekhar Bhatta ${ }^{2}$ \\ 1. Internal Medicine, Tribhuvan University Institute of Medicine, Kathmandu, NPL 2. Maharajgunj \\ Medical Campus, Tribhuvan University Institute of Medicine
}

$\square$ Corresponding author: Gaurav Nepal, gauravnepal@iom.edu.np

Disclosures can be found in Additional Information at the end of the article

\section{Abstract}

Antibiotics are essential treatments, especially in the developing world like World Health Organization (WHO) Southeast Asian region where infectious diseases are still the most common cause of death. In this part of the world, antibiotics are purchased and used without the prescription of a physician. Self-medication of antibiotics is associated with the risk of inappropriate drug use, which predisposes patients to drug interactions, masking symptoms of an underlying disease, and development of microbial resistance. Antibiotic resistance is shrinking the range of effective antibiotics and is a global health problem. The appearance of multidrug-resistant bacterial strains, which are highly resistant to many antibiotic classes, has raised a major concern regarding antibiotic resistance worldwide. Even after decades of economic growth and development in countries that belong to the WHO Southeast Asian region, most of the countries in this region still have a high burden of infectious diseases. The magnitude and consequence of self-medication with antibiotics is unknown in this region. There is a need for evidence from well-designed studies on community use of antibiotics in these settings to help in planning and implementing specific strategies and interventions to prevent their irrational use and consequently to reduce the spread of antibiotic resistance. To quantify the frequency and effect of self-medication with antibiotics, we did a systematic review of published work from the Southeast Asian region.

Categories: Family/General Practice, Infectious Disease, Epidemiology/Public Health

Keywords: antibiotics, self-medication, southeast asia

\section{Introduction And Background}

Antibiotics are among the most commonly purchased drugs worldwide [1]. They are essential treatments, especially in the developing world where infectious diseases are still the most common cause of death [2]. Self-medication refers to the use of medicines to treat selfdiagnosed disorders without consulting a medical practitioner and without any medical supervision [3]. It is a form of healthcare practiced in most parts of the world and overall 50\% of total antibiotics used are purchased over-the-counter [4-5]. Repercussions of self-medication with antibiotics leading to health hazards, particularly in the developing world, are multifaceted as they are linked to poverty, inaccessibility, lack of medical professionals, poor quality of healthcare facilities, unregulated distribution of medicines, and patients' misconceptions about physicians [6-7].

Self-medication of antibiotics is associated with the risk of inappropriate drug use, which predisposes patients to drug interactions, masking symptoms of an underlying disease, and the 
development of microbial resistance [8-9]. The inappropriate drug use practices common in self-medication include short duration of treatment, inadequate dose, sharing of medicines, and avoidance of treatment upon the improvement of disease symptoms [10]. The appearance of multidrug-resistant bacterial strains, which are highly resistant to many antibiotic classes, has raised a major concern regarding antibiotic resistance worldwide. This resistance may result in prolonged illnesses, more doctor visits, extended hospital stays, the need for more expensive medications, and even death [11].

Although various individual studies have examined antibiotic self-medication in countries that belong to the World Health Organization Southeast Asia region (WHO SEAR), there has not been a systematic review done in this setting. Even after decades of economic growth and development in countries that belong to the WHO SEAR, most of the countries in this region still have a high burden of infectious diseases [12]. There is a need for evidence from welldesigned studies on the community use of antibiotics in these settings to help in planning and implementing specific strategies and interventions to prevent their irrational use and consequently to reduce the spread of antibiotic resistance. To quantify the frequency and effect of self-medication with antibiotics, we did a systematic review of published work from WHO SEAR.

\section{Review}

\section{Methods}

Search Strategy

Databases (PubMed, PubMed Central, and Google Scholar) were searched for peer-reviewed research published between January 2000 and January 2018. The search terms, viz. antimicrobial, antibiotics, antibacterial, self-medication, and non-prescription combined with the name of countries that belong to the WHO SEAR, were used. Medical subject headings (MeSH) of the search terms were used in each case to maintain common terms across all databases searched. A thorough review of the references revealed further relevant articles.

\section{Selection Criteria}

Studies published in the English language were included in the review if they aimed to assess self-medication of antibiotics in countries that belong to WHO SEAR. Studies on antivirals, antifungals, antiprotozoal, and topical antimicrobials were excluded. In addition, studies dealing with self-medication of overall drugs, editorials, correspondences, and letters to the editor were also debarred. A Preferred Reporting Items for Systematic Reviews and MetaAnalyses (PRISMA) diagram detailing the study identification and selection process is given in Figure 1. 


\section{Cureus}

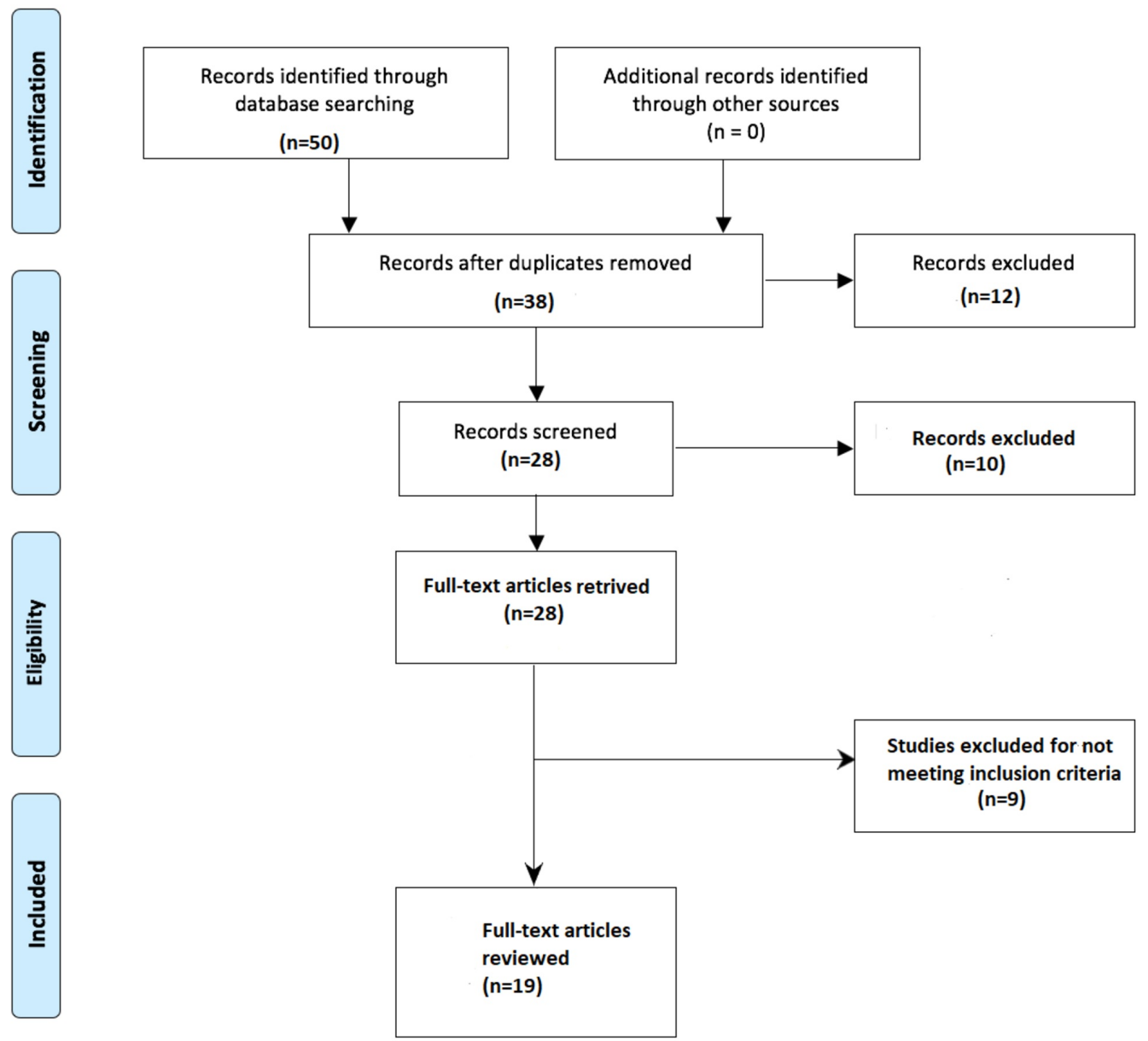

\section{FIGURE 1: PRISMA diagram detailing the study identification and selection process}

PRISMA: Preferred Reporting Items for Systematic Reviews and Meta-Analyses

\section{Data Abstraction}

The authors screened the articles based on the inclusion/exclusion criteria. Full texts were obtained for articles that met inclusion criteria. Authors developed a data abstraction spreadsheet using Microsoft Excel version 2013 (Microsoft Corp., Redmond, WA, USA) and included the following information: author, year of publication, journal, country where the study was done, recall period, study design, sample size, population sampled, prevalence of antimicrobial self-medication, type of antimicrobial agents used, source of drugs, disease symptoms, and inappropriate drug use practices.

\section{Results}

\section{Study Selection}

The initial electronic search identified 50 articles. After adjustment for duplicates, 38 remained. Of these, 10 studies were discarded, since, after review of their titles and abstracts, they did not meet the criteria. The full texts of the remaining 28 studies were reviewed in detail. Nine studies were cast away after the full text had been reviewed since they did not address much of 


\section{Cureus}

the needed information. Finally, 19 studies were included in the review. A PRISMA diagram detailing the study identification and selection process is given in Figure 1.

\section{Study Characteristics}

Almost all 19 studies differed in their setting, recall period, sample size, and study subjects. The studies covered 11,197 participants and the sample size ranged from 110 to 2,996. All studies included in this review were cross-sectional surveys. The studies were performed in WHO SEAR (Bhutan, Bangladesh, India, Indonesia, South Korea, Nepal, Srilanka, and Thailand) and illustrated in Figure 2. No studies were available from three countries of WHO SEAR (Myanmar, Maldives, and Timor-Leste). The recall period used in data collection varied among the different studies, ranging from one month to one year. A recall period was not available for all included studies. Studies were conducted among the general public, university students, and medical professionals. A detailed description of the characteristics of individual studies is provided in Table 1 .

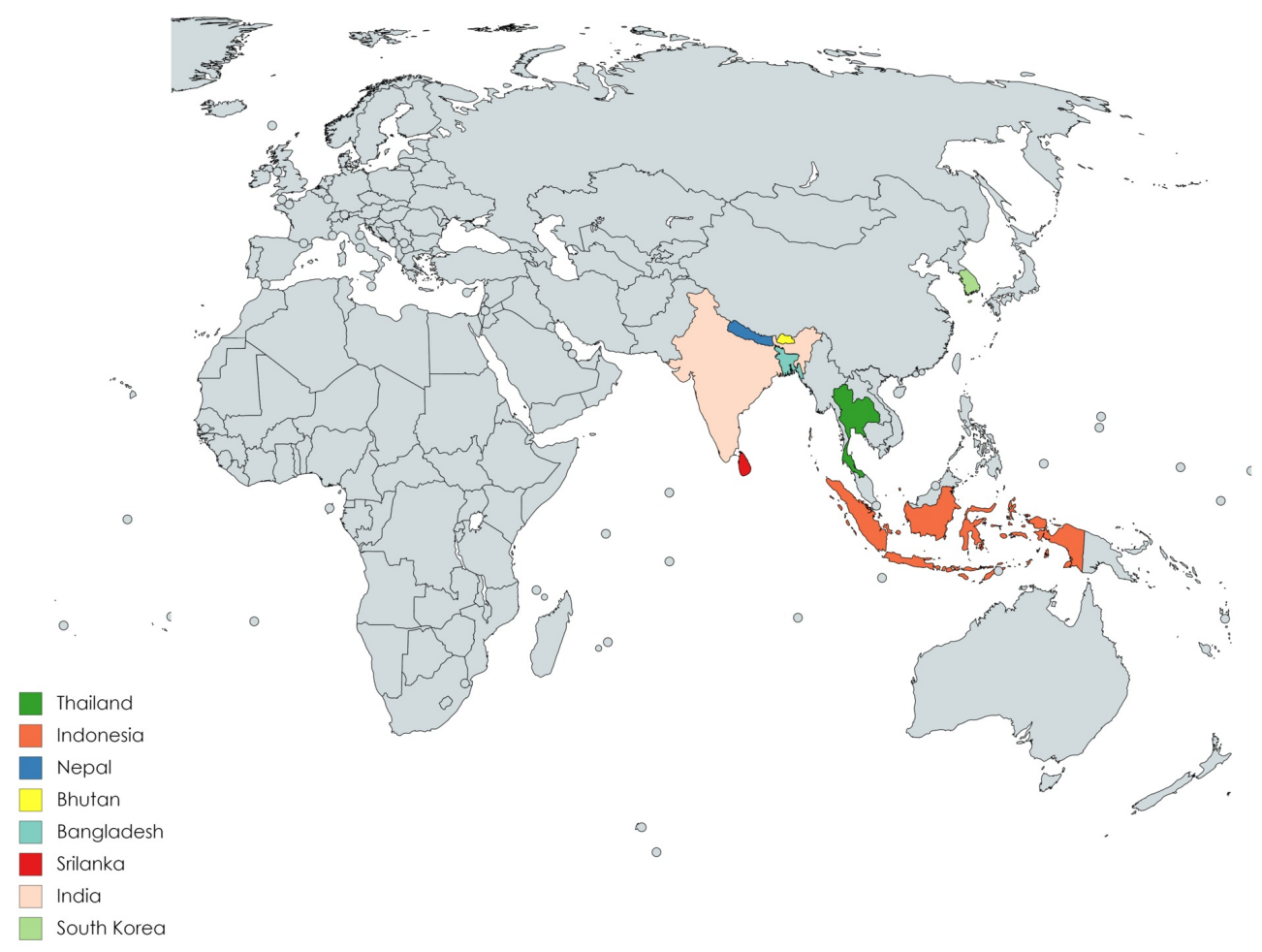

FIGURE 2: Countries included in this study

\begin{tabular}{|c|c|c|c|c|c|c|c|}
\hline Study & Country & Year & Design & $\begin{array}{l}\text { Recall } \\
\text { time }\end{array}$ & $\begin{array}{l}\text { Sample } \\
\text { size }\end{array}$ & Subjects & $\begin{array}{l}\text { SMA } \\
\text { Prevalence (\%) }\end{array}$ \\
\hline $\begin{array}{l}\text { Tshokey et al. } \\
\text { [13] }\end{array}$ & Bhutan & 2017 & $\begin{array}{l}\text { cross-sectional } \\
\text { survey }\end{array}$ & NA & 692 & General public & $23.6 \%$ \\
\hline $\begin{array}{l}\text { Biswas et al. } \\
{[14]}\end{array}$ & Bangladesh & 2014 & $\begin{array}{l}\text { cross-sectional } \\
\text { survey }\end{array}$ & $\begin{array}{l}3 \\
\text { months }\end{array}$ & 1300 & General public & $26.69 \%$ \\
\hline Seam et al. [15] & Bangladesh & 2018 & $\begin{array}{l}\text { cross-sectional } \\
\text { survey }\end{array}$ & NA & 250 & Pharmacy students & $15.6 \%$ \\
\hline
\end{tabular}




\section{Cureus}

\begin{tabular}{|c|c|c|c|c|c|c|c|}
\hline $\begin{array}{l}\text { Shubha et al. } \\
{[16]}\end{array}$ & India & 2013 & $\begin{array}{l}\text { cross-sectional } \\
\text { survey }\end{array}$ & NA & 110 & Dentists & $78.18 \%$ \\
\hline $\begin{array}{l}\text { Biswas et al. } \\
{[17]}\end{array}$ & India & 2015 & $\begin{array}{l}\text { cross-sectional } \\
\text { survey }\end{array}$ & $\begin{array}{l}6 \\
\text { months }\end{array}$ & 164 & Nursing students & $54.2 \%$ \\
\hline Nair et al. [18] & India & 2015 & $\begin{array}{l}\text { cross-sectional } \\
\text { survey }\end{array}$ & 1 year & 221 & Medical students & $85.59 \%$ \\
\hline $\begin{array}{l}\text { Ahmad et al. } \\
{[19]}\end{array}$ & India & 2012 & $\begin{array}{l}\text { cross-sectional } \\
\text { survey }\end{array}$ & NA & 600 & General public & $33.5 \%$ \\
\hline Pal et al. [20] & India & 2016 & $\begin{array}{l}\text { cross-sectional } \\
\text { survey }\end{array}$ & NA & 216 & $\begin{array}{l}\text { Medical and pharmacy } \\
\text { students }\end{array}$ & $75 \%$ \\
\hline $\begin{array}{l}\text { Virmani et al. } \\
{[21]}\end{array}$ & India & 2017 & $\begin{array}{l}\text { cross-sectional } \\
\text { survey }\end{array}$ & 1 years & 456 & $\begin{array}{l}\text { Health science } \\
\text { students }\end{array}$ & $60 \%$ \\
\hline $\begin{array}{l}\text { Ganesan et al. } \\
\text { [22] }\end{array}$ & India & 2014 & $\begin{array}{l}\text { cross-sectional } \\
\text { survey }\end{array}$ & NA & 781 & General public & $39.4 \%$ \\
\hline $\begin{array}{l}\text { Widayati et al. } \\
\text { [23] }\end{array}$ & Indonesia & 2011 & $\begin{array}{l}\text { cross-sectional } \\
\text { survey }\end{array}$ & 1 month & 559 & General public & $7.3 \%$ \\
\hline Hadi et al. [24] & Indonesia & 2008 & $\begin{array}{l}\text { cross-sectional } \\
\text { survey }\end{array}$ & 1 month & 2996 & General public & $16 \%$ \\
\hline $\begin{array}{l}\text { Kurniawan et } \\
\text { al. [25] }\end{array}$ & Indonesia & 2015 & $\begin{array}{l}\text { cross-sectional } \\
\text { survey }\end{array}$ & $\begin{array}{l}6 \\
\text { months }\end{array}$ & 400 & General public & $45 \%$ \\
\hline Kim et al. [26] & Korea & 2011 & $\begin{array}{l}\text { cross-sectional } \\
\text { survey }\end{array}$ & NA & 1,177 & General public & $46.9 \%$ \\
\hline Sah et al. [27] & Nepal & 2016 & $\begin{array}{l}\text { cross-sectional } \\
\text { survey }\end{array}$ & NA & 327 & Nursing students & $50.7 \%$ \\
\hline Pant et al. [28] & Nepal & 2015 & $\begin{array}{l}\text { cross-sectional } \\
\text { survey }\end{array}$ & 1 year & 168 & Dental students & $35.1 \%$ \\
\hline $\begin{array}{l}\text { Banerjee et al. } \\
\text { [29] }\end{array}$ & Nepal & 2016 & $\begin{array}{l}\text { cross-sectional } \\
\text { survey }\end{array}$ & NA & 488 & Medical students & $26.2 \%$ \\
\hline $\begin{array}{l}\text { Rathish et al. } \\
\text { [30] }\end{array}$ & Sri Lanka & 2017 & $\begin{array}{l}\text { cross-sectional } \\
\text { survey }\end{array}$ & 1 month & 696 & Medical students & $39 \%$ \\
\hline $\begin{array}{l}\text { Sirijoti et al. } \\
{[31]}\end{array}$ & Thailand & 2014 & $\begin{array}{l}\text { cross-sectional } \\
\text { survey }\end{array}$ & $\begin{array}{l}3 \\
\text { months }\end{array}$ & 396 & General public & $37.37 \%$ \\
\hline
\end{tabular}

\section{TABLE 1: Key Characteristics of Included Studies}

NA: not available; SMA: Self medication with antibiotics 


\section{Cureus}

The prevalence of self-medication with antibiotics (SMA) ranged from 7.3\% to $85.59 \%$ with an overall prevalence of $42.64 \%$. Prevalence rates differed greatly between countries and study subjects, as is summarized in Table 1. A high prevalence was reported from India and Nepal, and a low prevalence was reported from Indonesia and Bangladesh. The prevalence of SMA was higher among men in most studies. The prevalence of SMA was higher among health students and health professionals and was low among the general public.

\section{Common Illnesses and Reasons that Led to Self-Medication}

The common cold, sore throat, fever, gastrointestinal tract diseases, and respiratory diseases were the commonest illnesses or symptoms for which self-medication was taken. The major reasons behind the frequent practice of SMA were prior experiences of treating a similar illness, ignorance regarding the seriousness of the disease, an assured feeling of not requiring a visit to the physician, less expensive and easily affordable in terms of time and money, knowledge of the antibiotics, and suggestions from others. Table 2 shows the illnesses that resulted in selfmedication and the reasons that drove people to practice self-medication as reported in each study.

\begin{tabular}{|c|c|c|}
\hline Study & Illnesses & Reasons \\
\hline $\begin{array}{l}\text { Tshokey } \\
\text { et al. [13] }\end{array}$ & NA & NA \\
\hline $\begin{array}{l}\text { Biswas et } \\
\text { al. [14] }\end{array}$ & $\begin{array}{l}\text { GIT problems (36.02\%) Cold, cough and fever } \\
(28.24 \%) \text { Infection }(12.97 \%)\end{array}$ & $\begin{array}{l}\text { Pre-experience (45.82\%) Suggestions from others } \\
(28.24 \%) \text { Knowledge of the antibiotics }(16.14 \%) \\
\text { Reduction of doctor's fees }(6.34 \%) \text { No confidence } \\
\text { with doctor's medication }(3.46 \%)\end{array}$ \\
\hline $\begin{array}{l}\text { Seam et } \\
\text { al. [15] }\end{array}$ & NA & $\begin{array}{l}\text { Old prescription Academic knowledge Internet } \\
\text { Advertisement Friends }\end{array}$ \\
\hline $\begin{array}{l}\text { Shubha et } \\
\text { al. [16] }\end{array}$ & $\begin{array}{l}\text { Sore throat }(44.19 \%) \text { Common cold }(41.86 \%) \\
\text { Toothache }(39.53 \%) \text { Diarrhea }(24.42 \%) \text { Flu }(9.30 \%) \\
\text { Other respiratory conditions }(5.81 \%)\end{array}$ & $\begin{array}{l}\text { Being a dentist }(40 \%) \text { previous prescription } \\
(16.87 \%) \text { Considering the symptoms as minor } \\
(14.46 \%)\end{array}$ \\
\hline $\begin{array}{l}\text { Biswas et } \\
\text { al. [17] }\end{array}$ & $\begin{array}{l}\text { Common-cold Cough Sore throat, diarrhea, fever } \\
\text { Burning micturition Skin infections }\end{array}$ & NA \\
\hline $\begin{array}{l}\text { Nair et al. } \\
{[18]}\end{array}$ & $\begin{array}{l}\text { Common cold, cough, and sore throat }(62.4 \%) \text { Fever } \\
(25.3 \%) \text { Gastrointestinal tract infections }(18.6 \%)\end{array}$ & $\begin{array}{l}\text { Easier to apply previous prescription (46.6\%) } \\
\text { Convenience }(21.7 \%) \text { Good knowledge of } \\
\text { antibiotics }(11.3 \%)\end{array}$ \\
\hline $\begin{array}{l}\text { Ahmad et } \\
\text { al. [19] }\end{array}$ & $\begin{array}{l}\text { Respiratory tract infection (16.83\%), wound infection } \\
(14.5 \%) \text { Cough and cold }(14.5 \%) \text { Gastrointestinal tract } \\
\text { infection }(13.66 \%) \text { Fever }(13.66 \%) \text { Skin disorders } \\
(13 \%) \text { Eye and ear infections }(7 \%) \text {, Acne }(2.33 \%) \text {, } \\
\text { Urinary tract infections }(1 \%) \text { Other diseases }(3.5 \%)\end{array}$ & $\begin{array}{l}\text { Disease is simple }(21.83 \%) \text { Treatment cost is high } \\
\text { in hospitals }(30 \%) \text { Previous experience with the } \\
\text { disease }(8.16 \%) \text { Lack of hospitals in the nearest } \\
\text { place }(8.16 \%) \text { Patient knows about the drug and } \\
\text { disease }(11.5 \%) \text { Lack of trust in medical service } \\
(4 \%)\end{array}$ \\
\hline $\begin{array}{l}\text { Pal et al. } \\
\text { [20] }\end{array}$ & $\begin{array}{l}\text { Medical students: fever }(48.4 \%) \text {, diarrhea }(47.6 \%) \text {, } \\
\text { cough }(46 \%) \text {, sore throat }(43.6 \%) \text { Pharmacy students: } \\
\text { fever }(46.8 \%) \text {, cough }(30.6 \%) \text {, sore throat }(29.7 \%) \text {, } \\
\text { and diarrhea }(23.4 \%)\end{array}$ & $\begin{array}{l}\text { Sufficient pharmacological knowledge Timesaving } \\
\text { Avoiding crowd at OPD Cost saving }\end{array}$ \\
\hline
\end{tabular}




\section{Cureus}

Virmani et

al. [21]

Ganesan

et al. [22]

Widayati

et al. [23]

Hadi et al.

[24]

Kurniawan

et al. [25]

Wounds or skin diseases (32.2\%) Acute respiratory infections (18.3\%) Fever (11.7\%)

Kim et al.

[26]

Sah et al.

[27]

Pant et al. Fever (39.0\%) followed by sore throat, cough, diarrhoea, and runny nose

\section{Banerjee}

et al. [29]

Rathish et

al. [30]

Sirijoti et

al. [31]

Middle ear infection Clear nasal discharge Purulent nasal discharge Sore throat Flu-like symptoms Skin infections

Coughs and sore throat Cold and fever Ear infections Flu conditions Toothache

Common-cold, including cough, sore throat, headache, and other minor symptoms

NA

NA

Fever (35.7\%) Sore throat (20.2\%) Rhinitis (12.5\%)

NA

Sore throat (46\%): most common Runny nose, Flu Diarrhea
NA

\section{NA}

Previous experience Saving time Saving money

NA

More practical than seeking a doctor Too busy to see a doctor Previous experience No money to pay for doctor

NA

Good knowledge of antibiotic (46.2\%) Doctor advice is not needed for common illness (32\%) To save time and money (21.3\%)

Previous prescriptions (42.4\% ) Recommended by pharmacists (37.3\%) Own experience $(25.4 \%)$ Opinion of family and friends (18.7\%)

NA

Previous experience No access to physician care

Buy antibiotics yourself by bringing old antibiotics packaging or the sample of used antibiotics Buy antibiotics yourself by suggestions from your friends and family Advertisement

\section{TABLE 2: Illnesses and Reasons for Self-medication with Antibiotics}

NA: not available; OPD: outpatient department; GIT: gastrointestinal tract

Source of Medicines

The majority of the antimicrobial drugs used in self-medication were obtained from various sources, such as pharmacies, leftover drugs, hospitals, and from friends and family. The use of self-medication was commonly suggested by pharmacy professionals, friends, family, and relatives among the general public, whereas among health students and health professionals, self-medication was because of knowledge of medicine and pharmacology. 


\section{Cureus}

The most common antibiotic used for self-medication was amoxicillin, followed by macrolides, fluoroquinolones, cephalosporins, and metronidazole [14, 16-25, 27-30]. Antibiotics used for self-medication in each of the included studies are given in Table 3. Of the 19 studies included in the review, four did not investigate the types of antibiotics used in self-medication $[13,15$, 26, 31]. Among the macrolides, azithromycin use was most common, and among the fluoroquinolones, ciprofloxacin use was most common.

\section{Inappropriate Use of Antibiotics}

Only seven studies included in the review reported the inappropriate use of antibiotics [13, 16, 20-21, 26, 28, 31]. The most inappropriate practice was an abrupt stoppage of the antibiotic course after the disappearance of symptoms. Other improper practices were sharing antibiotics, saving antibiotics for future use, and switching antibiotics if symptoms were not relieved.

\begin{tabular}{|c|c|c|c|}
\hline Study & Inappropriate drug use & Most common antibiotics used & $\begin{array}{l}\text { Source of } \\
\text { drugs }\end{array}$ \\
\hline $\begin{array}{l}\text { Tshokey } \\
\text { et al. [13] }\end{array}$ & $\begin{array}{l}13.1 \% \text { shared antibiotics with other } \\
\text { people } 19.0 \% \text { saved antibiotics for later } \\
\text { use }\end{array}$ & NA & NA \\
\hline $\begin{array}{l}\text { Biswas et } \\
\text { al. [14] }\end{array}$ & NA & $\begin{array}{l}\text { Metronidazole (50.43\%) Azithromycin }(20.75 \%) \\
\text { Ciprofloxacin }(11.53 \%) \text { Amoxicillin }(10.37 \%) \\
\text { Tetracycline }(7.49 \%)\end{array}$ & Pharmacies \\
\hline $\begin{array}{l}\text { Seam et } \\
\text { al. [15] }\end{array}$ & NA & NA & Pharmacies \\
\hline $\begin{array}{l}\text { Shubha et } \\
\text { al. [16] }\end{array}$ & $\begin{array}{l}\text { Switch-over of antibiotics inbetween } \\
(12.79 \%) \text { Abrupt stoppage (15.12\%) }\end{array}$ & $\begin{array}{l}\text { Amoxicillin (70.93\%) Azithromycin (20.06\%) } \\
\text { Ciprofloxacin (8.14\%) Metronidazole (5.81\%) } \\
\text { Ofloxacin }(4.65 \%)\end{array}$ & $\begin{array}{l}\text { Medicine at } \\
\text { home/clinic }\end{array}$ \\
\hline $\begin{array}{l}\text { Biswas et } \\
\text { al. [17] }\end{array}$ & NA & $\begin{array}{l}\text { Metronidazole }(67.4 \%) \text { Azithromycin (32.6\%) } \\
\text { Norfloxacin }(16.8 \%)\end{array}$ & $\begin{array}{l}\text { Leftover } \\
\text { medicines at } \\
\text { home } \\
\text { Pharmacies }\end{array}$ \\
\hline $\begin{array}{l}\text { Nair et al. } \\
{[18]}\end{array}$ & NA & $\begin{array}{l}\text { Azithromycin (34.4\%) Amoxicillin (29.4\%) } \\
\text { Fluoroquinolones (18.6\%) }\end{array}$ & $\begin{array}{l}\text { Pharmacies } \\
\text { Left-over drugs } \\
\text { from previous } \\
\text { prescriptions } \\
\text { Family/friends }\end{array}$ \\
\hline $\begin{array}{l}\text { Ahmad et } \\
\text { al. [19] }\end{array}$ & NA & $\begin{array}{l}24.16 \% \text { cephalosporin } 21.16 \% \text { of penicillin } \\
16.16 \% \text { of quinolone Tetracycline group } \\
(12.83 \%) \text { Sulfonamides }(10.16 \%) \text { Macrolide } \\
\text { groups of antibiotic }(4.83 \%) \text { Aminoglycoside } \\
(3.16 \%) \text { Metronidazole }(3.33 \%)\end{array}$ & $\begin{array}{l}\text { Family, } \\
\text { friends, and } \\
\text { neighbors } \\
\text { Pharmacies } \\
\text { Previous } \\
\text { prescription }\end{array}$ \\
\hline $\begin{array}{l}\text { Pal et al. } \\
\text { [20] }\end{array}$ & $\begin{array}{l}\text { Only } 72.2 \% \text { of medical students and } \\
33.3 \% \text { of pharmacy students took full } \\
\text { course of antibiotics }\end{array}$ & Amoxicillin Azithromycin & NA \\
\hline
\end{tabular}




\section{Cureus}

Virmani et Very few completed the course once al. [21] started

Ganesan

et al. [22]

Widayati

et al. [23]

Hadi et al.

[24]

NA

Kurniawan

et al. [25]

NA

NA

NA

Kim et al. $\quad 77.6 \%$ of respondents stopped taking [26] the medication when they felt better

Sah et al.

[27]

NA

Switched antibiotics Stopped the

Pant et al. antibiotic use after the disappearance of the symptoms Stopped before finishing the course in a few days regardless of the outcome

Banerjee

et al. [29]

Rathish et

al. [30]

NA

NA

Distribute to another person who has the same symptoms Stop taking

Sirijoti et

al. [31]

relieved Stock some antibiotics at
B-Lactams (Most common) Fluoroquinolones

Macrolides Tetracycline

Amoxicillin (most common) Erythromycin

Cephalosporin Azithromycin Norfloxacin

Amoxicillin (most common) Ampicillin

Fradiomisin-gramicidin Tetracycline

ciprofloxacin

Amoxicillin or ampicillin (most common)

Tetracycline Cotrimoxazole Chloramphenicol

Thiamphenicol

Amoxicillin (68.3\%) Ampicillin (26.1\%)

Cefadroxil (1.1\%) Others (5.3\%)

NA

Amoxicillin (33.9\%) Azithromycin (14.9\%)

Ciprofloxacin (13.7\%)

Amoxicillin (most common) Metronidazole

Azithromycin Ciprofloxacin Amoxicillin and

clavulanic combination Cephalexin Ofloxacillin

Amoxicillin Azithromycin

Amoxicillin (most common) Ciprofloxacin Coamoxiclav Tetracycline Azithromycin

Ciprofloxacin Cephalosporin
Pharmacies

Pharmacies

NA

Pharmacies

Friends Old

prescription

Pharmacies

Drug stores

Kiosks

Pharmacies

Drugstores

Friends and

relatives kiosks

Pharmacies

Stalls Leftover

antibiotics

Friends or

family

NA

NA

Pharmacies

Relatives or friends Leftover drugs at home

Leftover drugs

at home

Pharmacies

NA

home in case of emergency

TABLE 3: Antibiotics Used in Self-medication, Inappropriate Use, and Source

NA: not available 


\section{Discussion}

The main finding of this review is that there are many published studies to indicate that the prevalence of SMA is alarmingly high among member countries of WHO SEAR. The prevalence of self-medication varied across the studies reviewed, ranging from $7.3 \%$ to $85.59 \%$, with an overall prevalence of $42.64 \%$. The main reasons for the wide variation in the prevalence of the self-medication practice may be differences in social determinants of health, tradition, culture, economic status, and developmental status. The difference in methodology, study setting, sample population, and recall time may also have contributed to this variation in prevalence of self-medication. A systematic review by Alhomoud et al. reported that the overall prevalence of self-medication varied from $19 \%$ to $82 \%$ in the Middle East [32]. A similar review by Ayalew et al. found that the prevalence of self-medication varied across the studies, ranging from $12.8 \%$ to $77.1 \%$ in Ethiopia [33]. The results of the current review are similar to those reported for SMA in the Euro-Mediterranean region [34] and developing countries [35]; the overall median proportions of self-medication reported for these countries were $40.9 \%$ and $38.8 \%$, respectively. Developed countries, such as those of Europe where over-the-counter antibiotic sales are strictly regulated, have much lower prevalence rates of SMA, ranging from $1 \%$ to $4 \%$ [36].

Comparatively, higher self-medication use was reported in studies conducted on health science students than the general public. This may be because of the better understanding of disease and drugs leading to a decreased inclination towards seeking physicians' help to treat their illnesses. Other studies conducted on health science students in different parts of the world have also reported a higher prevalence of self-medication practice [37-38]. Previous experience of treating a similar illness, feeling that the illness was mild and did not require the service of a physician, less expensive in terms of time and money, gaps in terms of knowledge, attitudes, and practices regarding antibiotic use, such as keeping leftover antibiotics for future use, sharing antibiotics with others, and belief that antibiotics can speed up recovery and eradicate any infection, were the most common reasons for SMA among the general public.

This review found that the main source of antibiotics used for self-medication were pharmacies, followed by friends and family. Pharmacists often do not have an adequate knowledge of the antimicrobial agents and the disease processes. However, they are commonly preferred as a source of advice or information for the antimicrobial agents obtained and used over-the-counter. Thus, pharmacists could play an important role in educating patients, rationalizing antibiotic use, and stopping antibiotic sales without a prescription.

Settings in which individuals are highly educated tend to have relatively low levels of use of antimicrobial self-medication. Therefore, awareness among communities is an important target to minimize antimicrobial self-medication in WHO SEAR. Due to their prior successful use of antimicrobial agents, individuals in most communities tend to believe that they can manage subsequent illnesses without consulting a physician. This is a potential risk factor for inappropriate drug use since most patients lack knowledge of the disease process and the medicines used in self-medication. The reasons for self-medication with antibiotics are different according to settings and are due to the complex network of a poor health system, social, economic, and health factors [39]. Therefore, establishing these factors is of paramount importance in designing and implementing programs against self-medication with antibiotics.

The underlying challenges of health systems in most countries of WHO SEAR, such as inadequate healthcare, potentially influence the use of self-medication [39]. In addition, the lack of policies or their inadequate implementation enables easy over-the-counter access of antibiotics [40]. Furthermore, most developing countries face the challenge of an irregular supply of drugs to the public health facilities, which limits community access to healthcare. This, coupled with the high burden of infectious diseases in these countries, makes the private 
sector an important alternative source of healthcare [41].

The common cold, sore throat, fever, gastrointestinal tract diseases, and respiratory diseases were the commonest illnesses or symptoms for which self-medication was taken. Fever and cold were indicated as the most frequent health complaint that led to self-medication in different studies [42-43]. There were also studies that reported respiratory diseases [44] and gastrointestinal (GI) tract diseases [45] as common illnesses for which self-medication was used. This may be because these illnesses are very common and occur frequently in individuals with experience in treating them. The mild and self-limiting nature of these illnesses may also prevent patients from seeking physician consultation. However, patients should not forget that when these illnesses/symptoms occur repeatedly or for prolonged periods, they should be investigated further by physicians, as they may be manifestations of serious illnesses.

Self-medication with antibiotics occurred with different antibiotic classes. The most common antibiotics used for self-medication was amoxicillin, followed by macrolides, fluoroquinolones, cephalosporins, and metronidazole. The high use of amoxicillin and fluoroquinolones may be due to the low cost, easy availability, and low side effect profiles. Amoxicillin, fluoroquinolones, and macrolides are also the most commonly prescribed antibiotics in this region and patients tend to use these prescriptions as a reference for similar illness in future [46-47]. Amoxicillin is a useful first-line antibiotic for acute otitis media, pneumonia, urinary tract infections, and other infections. Rampant, irrational use leads to resistance and treatment failure. Drugs from the quinolone group of antibiotics are reserved as second-line drugs for tuberculosis. Selfmedication and inappropriate use of ciprofloxacin make people vulnerable to drug-resistant tuberculosis.

The review established an inappropriate practice of antibiotic self-medication in communities of WHO SEAR. The most common inappropriate practice was an abrupt stoppage of a course of antibiotics after the disappearance of the symptoms. Another inappropriate practice was sharing antibiotics, saving antibiotics for future use, and switching antibiotics if symptoms were not relieved. However, the clinical outcomes of antibiotic self-medication were rarely reported in the articles from most studies in the WHO SEAR, probably because of a lack of awareness about the potentially harmful effects of antibiotics. These inappropriate uses potentially increase the risk of mistreatment, adverse drug reactions, drug interactions, and the development of resistance.

Some studies included in the review reported self-medication using multiple antimicrobial agents. The use of more than one antibiotic during an illness episode is indicative of the uncertainty of the cause of illness. These inappropriate practices potentially increase the risk of mistreatment, adverse drug reaction, development of resistance and drug interactions [8, 41]. This is further worsened by the high burden of infectious diseases in addition to the limited therapeutic choices in most WHO Southeast Asian countries [41]. Antibiotic resistance is likely to add further financial strains to the healthcare system, which currently is already facing the challenge of inadequate funding. This is especially the case as patients with resistant infections are likely to stay longer in hospitals and there is a need for more expensive second-line antibiotics. Agencies, such as the World Health Organization (WHO), the South Asian Association for Regional Cooperation (SAARC), the Association of Southeast Asian Nations (ASEAN), and the Ministry of Health of countries belonging to WHO SEAR, need to establish specific interventions focusing on these common inappropriate antibiotic use practices.

Thus, the situation can be changed in the WHO SEAR by enforcing and controlling laws and regulations related to the antibiotic dispensation in pharmacies and by increasing public awareness about the adverse drug reactions, development of superinfections, and antibioticresistance. These problems require appropriate measures by policymakers to develop pertinent 
policies, as well as to ensure their implementation.

\section{Conclusions}

The prevalence of SMA is comparatively high in the countries of WHO SEAR and is marked with inappropriate use of drugs, which is the leading cause of antibiotic resistance. Educational interventions targeting the general public, pharmacists, and healthcare students are of utmost importance. In addition, the improvement in the quality of healthcare facilities with easy access, law enforcement, and control regulations regarding the inappropriate use of antibiotics closely collaborating with public awareness about antibiotic resistance could alleviate and, ultimately, eradicate the challenge of SMA in this region. Since many patients get knowledge about drugs from the previous prescriptions, physicians should limit superfluous prescriptions of antibiotics and implement guideline-based practices. Pharmacists should also be morally encouraged to educate patients and rationalize antibiotic use by strictly stopping antibiotic sales without an authorized prescription by physicians.

\section{Additional Information}

\section{Disclosures}

Conflicts of interest: In compliance with the ICMJE uniform disclosure form, all authors declare the following: Payment/services info: All authors have declared that no financial support was received from any organization for the submitted work. Financial relationships: All authors have declared that they have no financial relationships at present or within the previous three years with any organizations that might have an interest in the submitted work. Other relationships: All authors have declared that there are no other relationships or activities that could appear to have influenced the submitted work.

\section{Acknowledgements}

We would like to thank Dhiraj Poudel, Prakriti Regmi, Om Prakash Bhatta, and Siddhartha Bhandari for proofreading this article.

\section{References}

1. Col NF, O'Connor RW: Estimating worldwide current antibiotic usage: report of Task Force 1 . Rev Infect Dis. 1987, 9:S232-43. 10.1093/clinids/9.Supplement 3.S232

2. Health statistics and information systems. The global burden of disease: 2004 Update . (2008). Accessed: March 18, 2018:

http://www.who.int/healthinfo/global_burden_disease/2004_report_update/en/.

3. Guidelines for the regulatory assessment of medicinal products for use in self-medication . (2000). Accessed: March 18, 2018: http://apps.who.int/iris/handle/10665/66154.

4. Högberg LD, Muller A, Zorzet A, et al.: Antibiotic use worldwide . Lancet Infect Dis. 2014, 14:1179-80. 10.1016/S1473-3099(14)70987-9

5. Morgan DJ, Okeke IN, Laxminarayan R, et al.: Non-prescription antimicrobial use worldwide: A systematic review . Lancet Infect Dis. 2011, 11:692-701. 10.1016/S1473-3099(11)70054-8

6. Hart CA, Kariuki S: Antimicrobial resistance in developing countries. BMJ. 1998, 317:647-50. 10.1136/bmj.317.7159.647

7. Istúriz RE, Carbon C: Antibiotic use in developing countries . Infect Control Hosp Epidemiol. 2000, 21:394-97. 10.1086/501780

8. Community-Based Surveillance of Antimicrobial Use and Resistance in Resource-Constrained Settings: Report on Five Pilot Projects. (2009). Accessed: March 18, 2018: http://apps.who.int/iris/handle/10665/70036.

9. Mehta U, Durrheim DN, Blumberg L, et al.: Malaria deaths as sentinel events to monitor healthcare delivery and antimalarial drug safety. Trop Med Int Health. 2007, 12:617-28.

10.1111/j.1365-3156.2007.01823.x 
10. Skliros E, Merkouris P, Papazafiropoulou A, et al.: Self-medication with antibiotics in rural population in Greece: a cross-sectional multicenter study. BMC Fam Pract. 2010, 11:58. 10.1186/1471-2296-11-58

11. Spellberg B, Guidos R, Gilbert D, et al.: The epidemic of antibiotic resistant infections: A call to action for the medical community from the Infectious Diseases Society of America. Clin Infect Dis. 2008, 46:155-64. 10.1086/524891

12. Gupta I, Guin P: Communicable diseases in the South-East Asia Region of the World Health Organization: towards a more effective response . Bull World Health Organ. 2010, 88:199-205. 10.2471/BLT.09.065540

13. Tshokey T, Adhikari D, Tshering T, et al.: Assessing the knowledge, attitudes, and practices on antibiotics among the general public attending the outpatient pharmacy units of hospitals in Bhutan: a cross-sectional survey. Asia Pac J Public Health. 2017, 29:580-88. 10.1177/1010539517734682

14. Biswas M, Roy MN, Manik MI, et al.: Self medicated antibiotics in Bangladesh: a crosssectional health survey conducted in the Rajshahi City. BMC Public Health. 2014, 14:847. 10.1186/1471-2458-14-847

15. Seam MO, Bhatta R, Saha BL, et al.: Assessing the perceptions and practice of self-medication among Bangladeshi undergraduate pharmacy students. Pharmacy (Basel). 2018, 6:pii: E6. 10.3390/pharmacy6010006

16. Shubha R, Savkar MK, Manjunath GN: Self-medication pattern among dentists with antibiotics. J Evol Med Dent Sciences. 2013, 2:9037-41.

17. Biswas S, Ghosh A, Mondal K, et al.: Self-medication with antibiotics among undergraduate nursing students of a government medical college in Eastern India. IJPR. 2015, 5:239-43.

18. Nair A, Doibale MK, Kulkarni SK, et al.: Pattern of selfmedication with antibiotics among undergraduate medical students of a government medical college. Int J Prev Public Health Sci. 2015, 1:9-13.

19. Ahmad A, Parimalakrishnan S, Patel I, et al.: Evaluation of self-medication antibiotics use pattern among patients attending community pharmacies in rural India, Uttar Pradesh. J Pharm Res. 2012, 5:765-68.

20. Pal B , Murti K, Gupta AK, et al.: Self medication with antibiotics among medical and pharmacy students in North India. Curr Res Med. 2016, 7:7-12. 10.3844/amjsp.2016.7.12

21. Virmani S, Nandigam M, Kapoor B, et al.: Antibiotic use among health science students in an Indian university: A cross sectional study. Clin Epidemiol Glob Health. 2017, 5:176-79. 10.1016/j.cegh.2017.04.005

22. Ganesan N, Subramanian S, Jaikumar RH, et al.: Self-medication and indiscriminate use of antibiotics without prescription in Chennai, India: a major public health problem. J Club Pharmaceutical Sciences. 2014, 1:131-41.

23. Widayati A, Suryawati S, de Crespigny C, Hiller JE: Self medication with antibiotics in Yogyakarta City Indonesia: a cross sectional population-based survey. BMC Res Notes. 2011, 4:491. 10.1186/1756-0500-4-491

24. Hadi U, Duerink DO, Lestari ES, et al.: Survey of antibiotic use of individuals visiting public healthcare facilities in Indonesia. Int J Infect Dis. 2008, 12:622-29. 10.1016/j.ijid.2008.01.002

25. Kurniawan K, Posangi J, Rampengan N: Association between public knowledge regarding antibiotics and self-medication with antibiotics in Teling Atas Community Health Center, East Indonesia. Med J Indonesia. 2017, 26:62-69. 10.13181/mji.v26i1.1589

26. Kim SS, Moon S, Kim EJ: Public knowledge and attitudes regarding antibiotic use in South Korea. J Korean Acad Nurs. 2011, 41:742-49. 10.4040/jkan.2011.41.6.742

27. Sah AK, Jha RK, Shah DK: Self-medication with antibiotics among nursing students of Nepal . IJPSR. 2016, 7:427-30.

28. Pant N, Sagtani RA, Pradhan M, et al.: Self-medication with antibiotics among dental students of Kathmandu - prevalence and practice. Nepal Med Coll J. 2015, 17:47-53.

29. Banerjee I, Sathian B, Gupta RK, et al.: Self-medication practice among preclinical university students in a medical school from the city of Pokhara, Nepal. Nepal J Epidemiol. 2016, 6:57481. 10.3126/nje.v6i2.15165

30. Rathish D, Wijerathne B, Bandara S, et al.: Pharmacology education and antibiotic selfmedication among medical students: a cross-sectional study. BMC Res Notes. 2017, 10:337. 10.1186/s13104-017-2688-4

31. Sirijoti K, Hongsranagon P, Havanond P, et al.: Assessment of knowledge attitudes and 
practices regarding antibiotic use in Trang province, Thailand. J Health Res. 2014, 28:299-307.

32. Alhomoud F, Aljamea Z, Almahasnah R, et al.: Self-medication and self-prescription with antibiotics in the Middle East-do they really happen? A systematic review of the prevalence, possible reasons, and outcomes. Int J Infect Dis. 2017, 57:3-12. 10.1016/j.ijid.2017.01.014

33. Ayalew MB: Self-medication practice in Ethiopia: a systematic review . Patient Prefer Adherence. 2017, 11:401-13. 10.2147/PPA.S131496

34. Scicluna EA, Borg MA, Gür D, et al.: Self-medication with antibiotics in the ambulatory care setting within the Euro-Mediterranean region; results from the ARMed project. J Infect Public Health. 2009, 2:189-97. 10.1016/j.jiph.2009.09.004

35. Ocan M, Obuku EA, Bwanga F, et al.: Household antimicrobial self-medication: a systematic review and metaanalysis of the burden, risk factors and outcomes in developing countries. BMC Public Health. 2015, 15:742. 10.1186/s12889-015-2109-3

36. Grigoryan L, Haaijer-Ruskamp FM, Burgerhof JG, et al.: Self-medication with antimicrobial drugs in Europe. Emerg Infect Dis. 2006, 12:452-59. 10.3201/eid1203.050992

37. Bollu M, Vasanthi B, Chowdary PS, et al.: Prevalence of self medication among the pharmacy students in Guntur: a questionnaire based study. World J Pharm Pharm Sci. 2014, 3:810-26.

38. Suaifan G, Shehadeh M, Darwish D, et al.: A cross-sectional study on knowledge, attitude and behavior related to antibiotic use and resistance among medical and non-medical university students in Jordan. Afr J Pharm Pharmacol. 2012, 6:763-70.

39. Radyowijati A, Haak H: Improving antibiotic use in low-income countries: an overview of evidence on determinants. Soc Sci Med. 2003, 57:733-44. 10.1016/S0277-9536(02)00422-7

40. The World Medicines Situation Report 2011. Medicine Expenditures . (2011). Accessed: March 17, 2018: http://www.who.int/health-accounts/documentation/world_medicine_situation.pdf? ua\%2520\&hx003D\%3b1.

41. Okeke IN, Klugman KP, Bhutta ZA, et al.: Antimicrobial resistance in developing countries. Part II: strategies for containment. Lancet Infect Dis. 2005, 5:568-80. 10.1016/S14733099(05)70217-6

42. Flaiti MA, Badi KA, Hakami WO, et al.: Evaluation of self-medication practices in acute diseases among university students in Oman. J Acute Dis. 2014, 3:249-52. 10.1016/S22216189(14)60056-1

43. Gaddam D : Assessment of self-medication practices among medical, pharmacy and nursing students at a tertiary care teaching hospital. Indian J Hosp Pharm. 2012, 49:79-83.

44. Jasim AL, Fadhil TA, Taher SS: Self-medication practice among Iraqi patients in Baghdad city. Am J Pharmacol Sci. 2014, 2:18-23.

45. Ali SE, Ibrahim MI, Palaian S: Medication storage and self-medication behaviour amongst female students in Malaysia. Pharm Pract (Granada). 2010, 8:226-32. 10.12691/ajps-2-1-4

46. Vanitha M, Vineela M, Benjamin RKP, et al.: Prescribing pattern of antibiotics in patients attending ENT OPD in a tertiary care hospital. IOSR-JDMS. 2017, 16:30-33.

47. Ramchandra K, Sanji N, Somashekar H S, et al.: Trends in prescribing antimicrobial in an ENT outpatients department of tertiary care hospital for upper respiratory tract infection. Int J Pharmacol and Clin Sci. 2012, 1:15-18. 